\title{
PENERAPAN SISTEM INFORMASI DALAM PENGELOLAAN REKAM MEDIS HASIL LABORATORIUM
}

\author{
Amanda Alfina[1]; Deddy Supriadi[2]; Bambang Kelana Simpony[3]; Herlan Sutisna ${ }^{[4]}$ \\ Program Studi Sistem Informasi[1][2][3][4] \\ Universitas Bina Sarana Informatika Kampus Kota Tasikmalaya[1][2][3][4] \\ www.bsi.ac.id $\left.{ }^{1}\right][2][3][4]$ \\ aalfina97@gmail.com ${ }^{[1]}$; deddy.dys@bsi.ac.id[2]; bambang.bky@bsi.ac.id[3]; herlan.her@bsi.ac.id[4]
}

\begin{abstract}
The laboratory is part of the health services needed to support efforts to improve health, prevention and treatment of patients. Fast, precise and accurate service can only be realized if the laboratory is supported by adequate and functioning facilities and infrastructure. One of the laboratories in Tasikmalaya, Bakti Tunas Husada Clinical Laboratory, has problems in making examination reports, recording examination reports, patient payment receipts, and income reports. All reports are still recorded in the book so that the problem that often occurs is an error in recording, takes a long time in making a letter examination of the patient because the laboratory examiner must enter the normal type and number of examinations. Another problem is that in payment transactions and income reports the examiner must record, calculate it manually and inaccurate income reports that are made and the delay in the search for necessary data. Website-shaped information systems are one alternative to solving problems and aim to help provide solutions to existing problems. This information system uses the waterfall method consisting of analysis, design, program code creation, testing and database designed with entity relationship diagrams. With the web-based application can simplify and speed up data processing such as making the results of inspection letters, receipt of automatic payments, and income reports.
\end{abstract}

Keywords: Information Systems, Laboratories, Web-Based Medical Records, Waterfall Methods

Intisari- Laboratorium merupakan bagian dari pelayanan kesehatan yang diperlukan untuk menunjang upaya peningkatan kesehatan, pencegahan dan pengobatan pasien. Pelayanan yang cepat, tepat dan cermat hanya dapat terwujud apabila laboratorium didukung oleh sarana dan prasarana yang memadai dan berfungsi dengan baik. Salah satu laboratorium di tasikmalaya yaitu Laboratorium Klinik Bakti Tunas Husada memiliki permasalahan dalam pembuatan laporan hasil pemeriksaan, pencatatan laporan pemeriksaan, struk pembayaran pasien, dan laporan pendapatan. Semua laporan masih dicatat di buku sehingga permasalahan yang sering terjadi adalah kesalahan dalam pencatatan, membutuhkan waktu lama dalam membuat surat hasil pemeriksaan pasien karena pemeriksa laboratorium harus memasukan jenis dan angka normal pemeriksaan. Masalah lainnya yaitu dalam transaksi pembayaran dan laporan pendapatan pemeriksa harus mencatat, menghitungnya secara manual dan kurang akuratnya laporan pendapatan yang dibuat dan keterlambatan pencarian data yang diperlukan. Sistem informasi berbentuk website merupakan salah satu alternatif pemecahan masalah dan bertujuan membantu memberi solusi dari permasalahan yang ada. Sistem informasi ini menggunakan metode waterfall terdiri dari analisis, desain, pembuatan kode program, pengujian serta database dirancang dengan entity relationship diagram. Dengan adanya aplikasi berbasis web dapat mempermudah dan mempercepat dalam pengolahan data seperti pembuatan surat hasil pemeriksaan, struk pembayaran otomatis, dan laporan pendapatan.

Kata Kunci: Sistem Informasi, Laboratorium, Rekam Medis Berbasis Web, Metode Waterfall.

\section{PENDAHULUAN}

Teknologi informasi adalah suatu teknologi yang digunakan untuk mengumpulkan, memproses, menyusun, menyimpan, dan memanipulasi data dalam berbagai cara untuk menghasilkan informasi yang berkualitas (relevan, akurat, dan tepat waktu), serta informasi yang berkualitas akan mempermudah seseorang dalam mengambil sebuah keputusan (Anori, Rukun, \& Huda, 2016).

Sistem informasi berbasis web adalah sebuah sistem informasi yang menggunakan internet untuk memberikan dan atau memperoleh informasi dan layanan dari dan untuk pengguna (Tamara \& Tulloh, 2018).

Sistem informasi di dunia medis diperlukan agar hasil tes dan lab lebih akurat, cepat, dan dipercaya. Laboratorium Klinik Bakti Tunas Husada sebagai sumber data di penelitian ini terdapat beberapa masalah dalam pembuatan laporan hasil pemeriksaan pasien, struk pembayaran pasien dan laporan pendapatan 
masih menggunakan sistem pencatatan di atas buku dan kertas. Berdasarkan hasil wawancara dengan petugas laboratorium dan ketua UPK Klinik, masalah yang timbul yaitu sulitnya dalam penghitungan manual pendapatan, pencarian data, kesalahan dalam pencatatan, durasi pengerjaan dalam laporan memerlukan waktu yang lama karena data yang ada tidak saling terintegrasi satu dengan lainnya.

Berdasarkan permasalahan diatas, maka diperlukan penerapan teknologi dalam mengolah sistem informasi sehingga dalam penyimpanan data bisa dilakukan dengan mudah, akurat, cepat dan data terintegrasi satu dengan lainnya. Salah satu alternatifnya bagaimana membuat sistem informasi berbasis website untuk memudahkan petugas laboratorium dalam mengolah data rekam medis yang berupa berkas yang berisi catatan dan dokumen tentang identitas pasien, pemeriksaan, pengobatan, tindakan dan pelayanan lain yang telah diberikan kepada pasien (Suprianto \& Matsea, 2018), laboratorium, pasien dan membuat laporan pendapatan serta laporan pasien.

\section{BAHAN DAN METODE}

Bahan untuk mendapatkan data di penilitian ini, penyusun mengerjakan beberapa langkah diantaranya dengan observasi atau pengamatan langsung mengenai rekam medis hasil laboratorium pada Klinik Bakti Tunas Husada Kota Tasikmalaya, sehingga didapat dokumen riil mengenai sistem yang sedang berjalan diantaranya formulir data pemeriksaan, buku catatan arsip dan catatan hasil lab manual. Dari bahan yang sudah ada ini bisa di analisis apakah sistem yang ada sudah berjalan sebagaimana mestinya dan menemukan keterkaitan antar dokumen apakah sudah berjalan dengan baik atau belum. Untuk melengkapi hasil analisis dokumen, maka dilanjutkan dengan wawancara untuk mendapatkan informasi secara lengkap ke salah satu petugas dan ketua yang ada di laboratorium tersebut.

Tahapan selanjutnya penyusun melakukan studi pustaka dari jurnal, buku dan informasi terkait lainnya yang dapat mendukung penyelesaian masalah. Tentunya judul penelitian jurnal dan buku yang ada hubungannnya dengan rekam medis.

Tahapan diatas merupakan tahapan pertama (Analisis Kebutuhan/requiremnets) dari model dalam pengembangan perangkat lunak menggunakan model Waterfall (A.S \& Shalahuddin, 2014) yang memiliki pendekatan alur hidup perangkat lunak secara terurut dimulai dari analisis, desain, pengkodean, pengujian dan tahap pendukung (support).

Tahapan kedua yaitu desain, penyusun menggunakan desain antar muka yaitu bagian back-end, rancangan ERD (Entity Relationship Diagram) dan LRS (Logical Record Structure), rancangan struktur navigasi. Tahapan ketiga yaitu Pembuatan Kode Program, website dirancang dan dibangun dengan menggunakan bahasa pemrograman PHP dan database MySQL, Selanjutnya Pengujian, fokus pada perangkat lunak serta memastikan bahwa semua bagian sudah diuji. Tahap akhir yaitu pendukung/pemeliharaan, ditahap ini tidak menutup kemungkinan mengulangi proses pengembangan mulai dari analisis dikarenakan adanya perubahan yang diakibatkan oleh kesalahan yang muncul dan tidak terdeteksi sebelumnya saat tahap pengujian (A.S \& Shalahuddin, 2014).

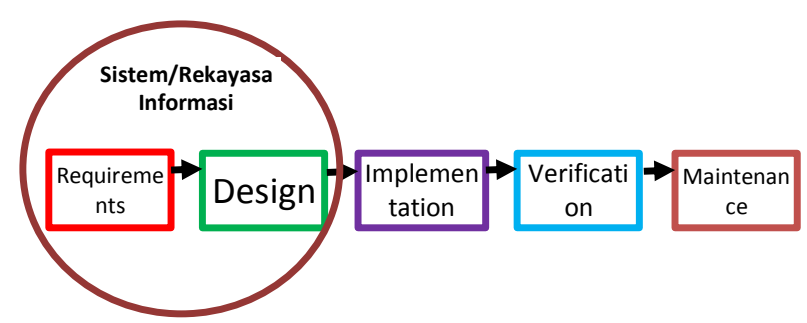

Sumber : (A.S \& Shalahuddin, 2014)

Gambar 1. Ilustrasi Model Waterfall

\section{HASIL DAN PEMBAHASAN}

\section{Analisa Kebutuhan}

Dalam aplikasi rekam medis hasil laboratorium ini, mempunyai 2 tingkatan pengguna dan 1 tingkatan yang menerima hasilnya, yaitu:

a. Pemeriksa laboratorium

Pemeriksa laboratorium mempunyai hak akses secara keseluruhan mulai dari melihat dan menginput data pasien, data dokter, data pelayanan, data spesimen, penginputan pemeriksaan, laporan pemeriksaan dan pemeriksa bisa menambah, mengubah dan menghapus data. Selain itu pemeriksa bisa menambah atau megubah admin dan asisten.

b. Asisten Laboratorium

Asisten laboratorium mempunyai hak akses mulai dari melihat dan menginput data pasien, data dokter, data pelayanan, data spesimen, penginputan pemeriksaan, laporan pemeriksaan dan bisa menambah, mengubah dan menghapus data. Tetapi tidak keseluruhan yaitu asisten tidak bisa melihat, menambah, mengubah dan menghapus data admin dan asisten. 
c. Pasien

Pasien didalam aplikasi ini tidak mempunyai hak akses untuk masuk ke dalam aplikasi, tetapi pasien menerima hasil dari pemeriksaan dan struk pembayaran pemeriksaan.

\section{ERD dan LRS}

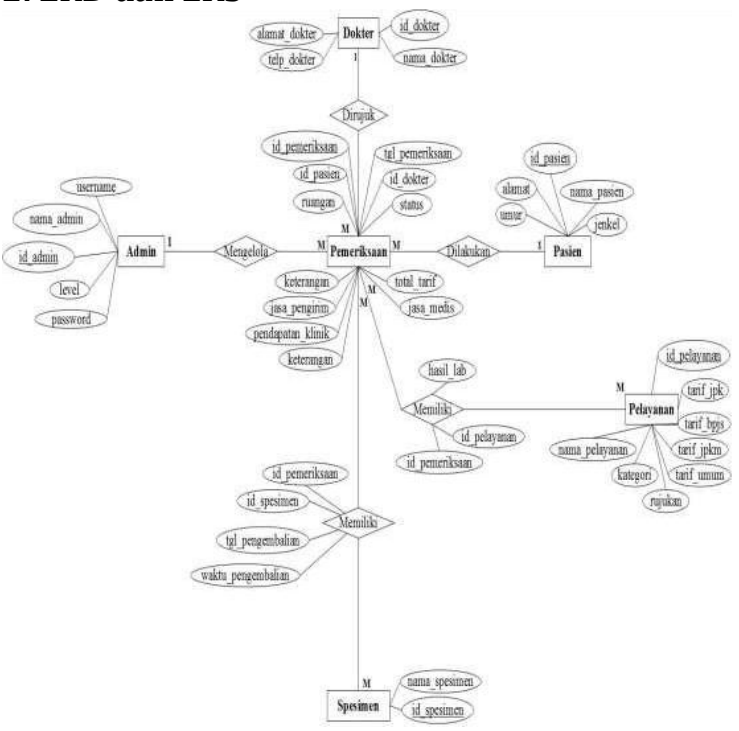

Sumber: Hasil Penelitian (2019)

Gambar 2. ERD Rekam Medis Hasil Laboratorium

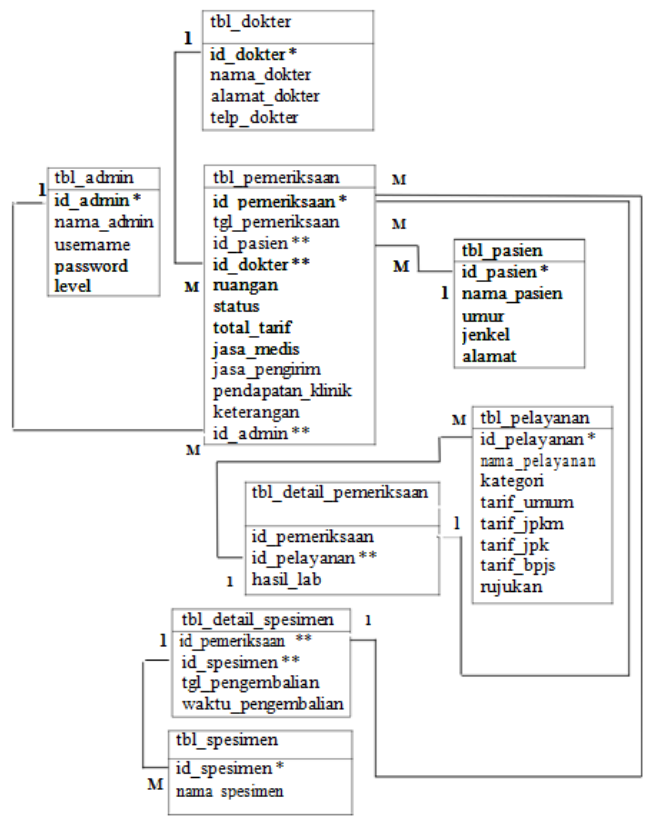

Sumber: Hasil Penelitian (2019)

Gambar 3. ERD Rekam Medis Hasil Laboratorium

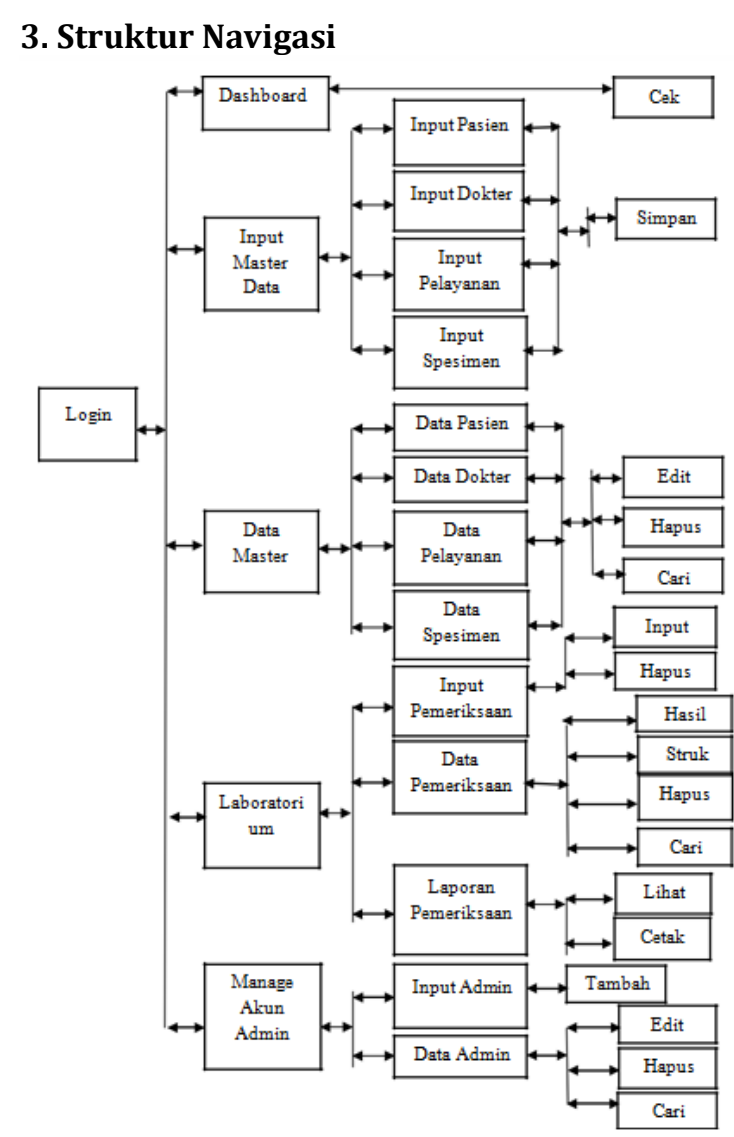

Sumber: Hasil Penelitian (2019)

Gambar 4. Struktur Navigasi Admin

\section{Rancangan Implementasi Antar Muka}

a.Halaman Login Admin

Pemeriksa laboratorium atau asisten harus melakukan login terlebih dahulu untuk membuat surat hasil pemeriksaan pasien, adapun menu tampilannya yaitu:

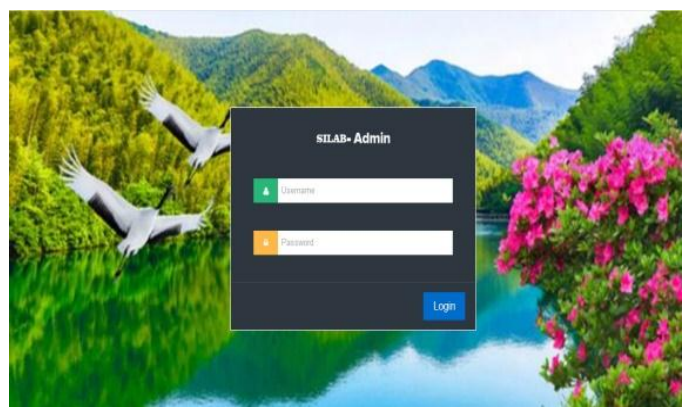

Sumber: Hasil Penelitian (2019)

Gambar 5. Halaman Login Admin

b.Halaman Beranda Admin

Halaman ini untuk menampilkan atau mengecek hasil laboratorium pasien berdasarkan ID pasien. Aksi yang ada disini yaitu Hasil dan Struk. 


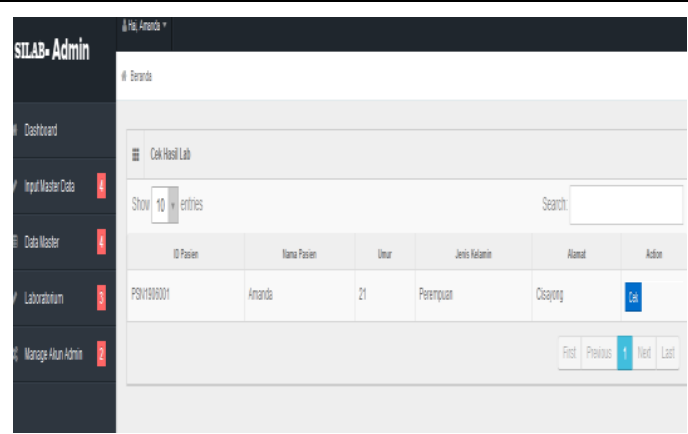

Sumber: Hasil Penelitian (2019)

Gambar 6. Halaman Beranda Admin

c.Halaman Input Pasien

Halaman ini berisi input data pasien dimana admin bisa menambahkan pasien baru.

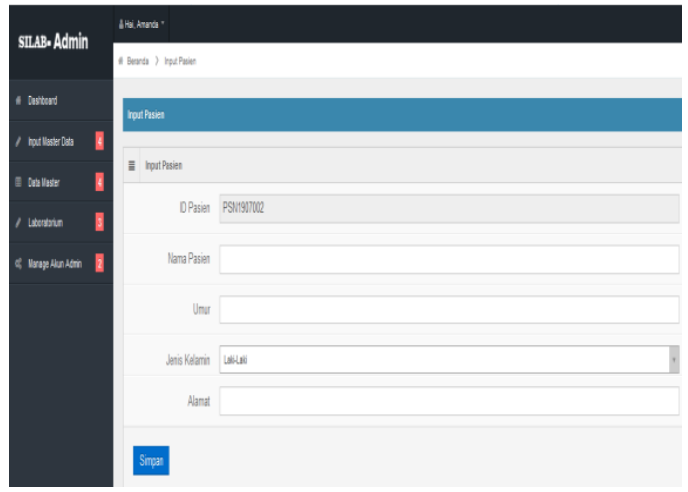

Sumber: Hasil Penelitian (2019)

Gambar 7. Halaman Input Pasien

d.Halaman Input Dokter

Halaman ini berisi master penginputan dokter dimana admin bisa menambahkan dokter baru.

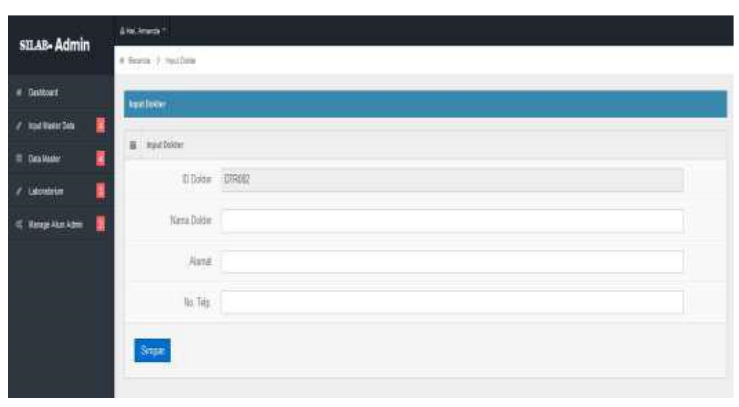

Sumber: Hasil Penelitian (2019)

Gambar 8. Halaman Input Dokter

e. Halaman Input Pelayanan

Halaman ini berisi master penginputan pelayanan dimana admin bisa menambahkan pelayanan baru laboratorium.

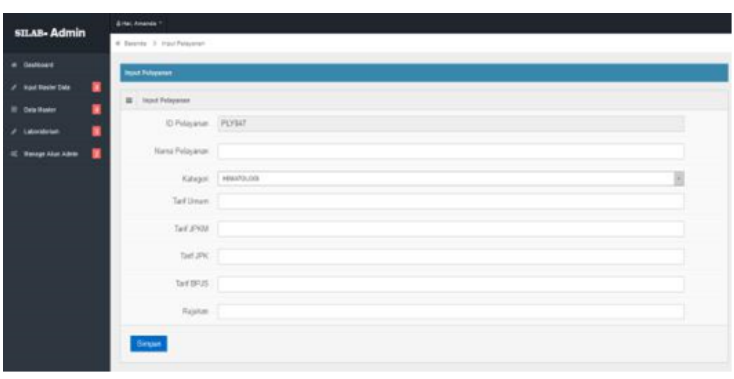

Sumber: Hasil Penelitian (2019)

Gambar 9. Halaman Input Pelayanan

f. Halaman Data Dokter

Berisi data master dokteri dimana admin bisa mengedit, menghapus dan mencarai data dokter

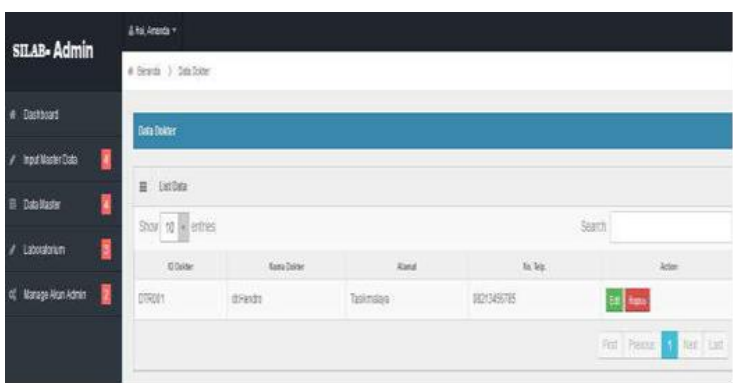

Sumber: Hasil Penelitian (2019)

Gambar 10. Halaman Data Master Dokter

g. Halaman Data Pelayanan

Berisi data master pelayanan dimana admin bisa mengedit, menghapus dan mencari data pelayanan yang ada di laboratorium

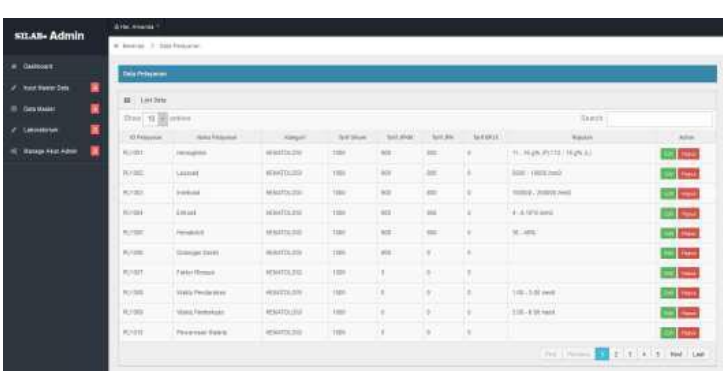

Sumber: Hasil Penelitian (2019)

Gambar 11. Halaman Data Master Pelayanan

h. Halaman Data Spesimen

Halaman ini berisi data master spesimen pemeriksaan dimana admin bisa mengedit, menghapus dan mencari data. 


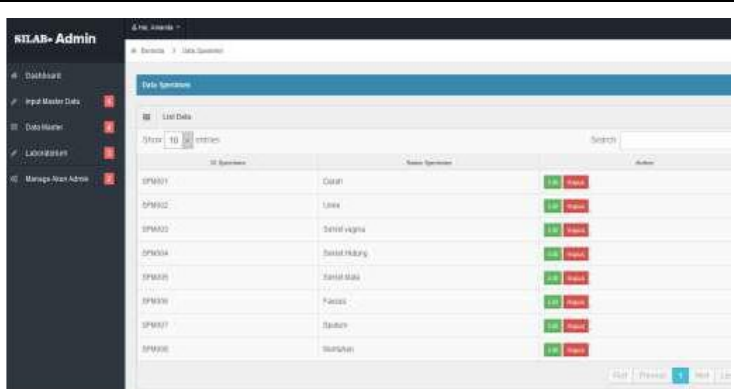

Sumber: Hasil Penelitian (2019)

Gambar 12. Halaman Data Master Spesimen

i.Halaman Laboratorium Input Pemeriksaan Halaman ini berisi halaman pemanggilan pasien yang akan diperiksa.

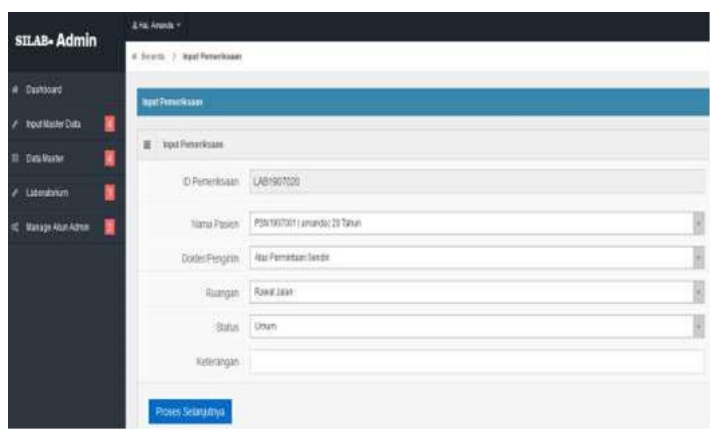

Sumber: Hasil Penelitian (2019)

Gambar 13. Halaman laboratorium input pemeriksaan

j.Halaman pilih pemeriksaan

Halaman ini berisi halaman pilih pemeriksaan pasien dengan jenis yang akan diperiksa.

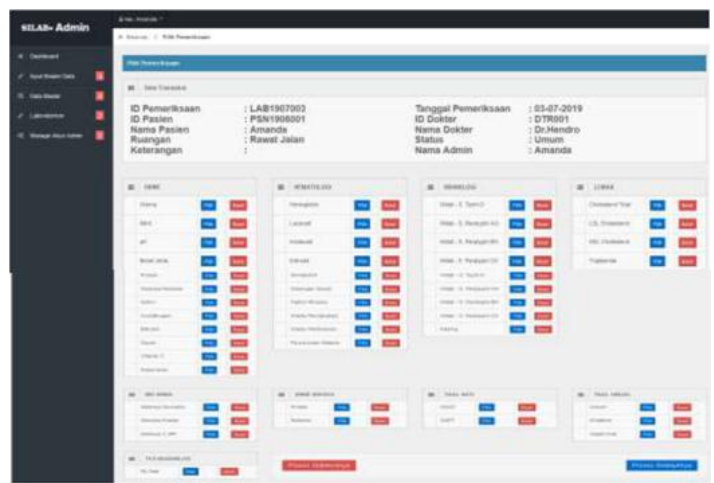

Sumber: Hasil Penelitian (2019)

Gambar 14. Halaman Pilih Pemeriksaan

k.Halaman Input Spesimen

Halaman ini berisi penginputan spesimen sesuai jenis pemeriksaan dan waktu pengambilan ketika spesimen pasien diambil atau diperiksa.

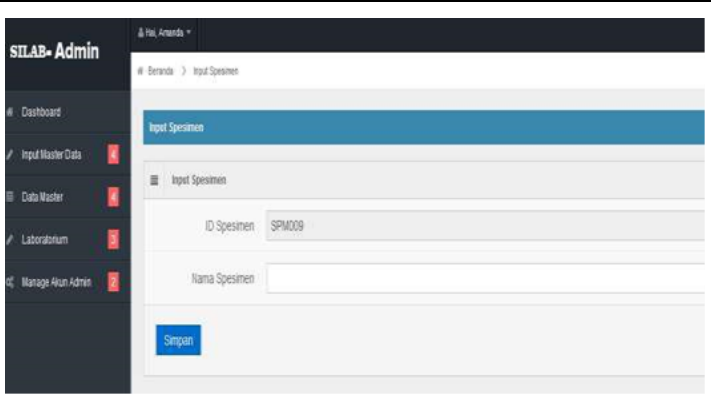

Sumber: Hasil Penelitian (2019)

Gambar 15. Halaman Input Spesimen

1.Halaman Data Pasien Sementara

Halaman ini berisi halaman data pasien sementara dengan aksi input hasil dan hapus.

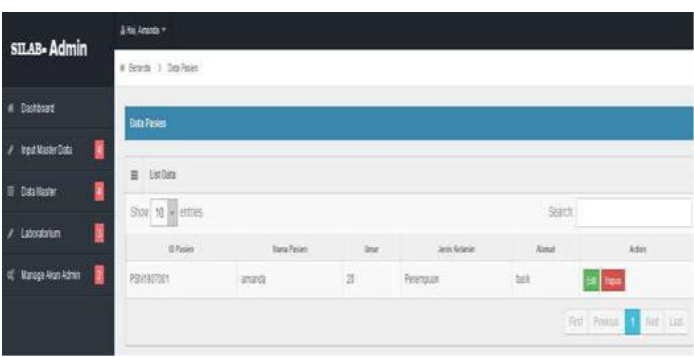

Sumber: Hasil Penelitian (2019)

Gambar 16. Halaman Data Master Pasien

m.Halaman Input Hasil Pemeriksaan

Halaman ini berisikan halaman penginputan hasil pemeriksaan pasien.

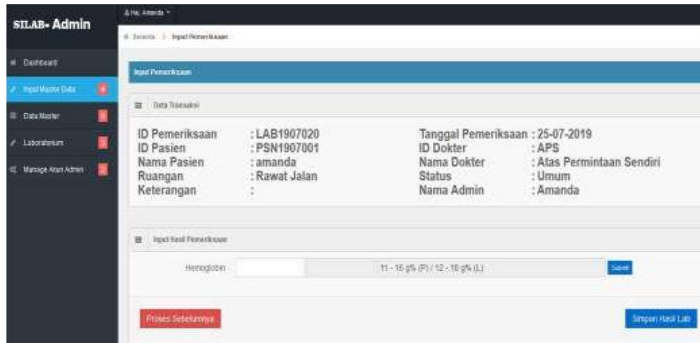

Sumber: Hasil Penelitian (2019)

Gambar 17. Input Pemeriksaan

n.Halaman Hasil Pemeriksaan

Halaman ini berisi surat hasil pemeriksaan pasien, dimana surat ini bisa dicetak.

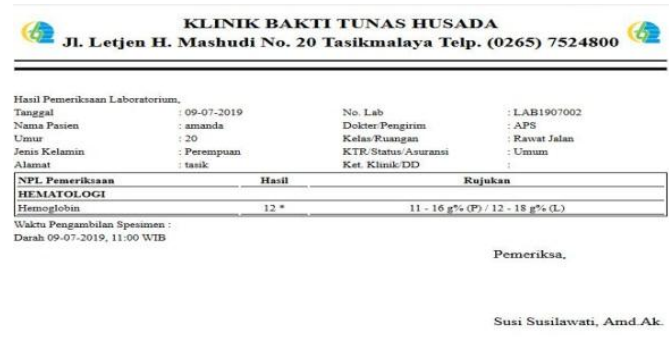

Sumber: Hasil Penelitian (2019)

Gambar 18. Halaman Hasil Pemeriksaan 
o.Halaman Struk

Halaman ini berisi transaksi pasien yang dilakukan pasien setelah melakukan pemeriksaan di laboratorium.

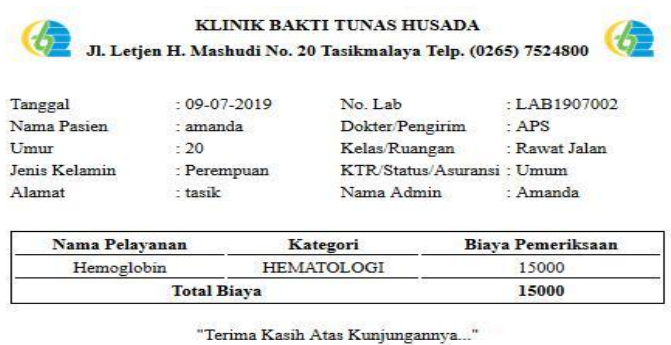

Sumber: Hasil Penelitian (2019)

Gambar 19. Halaman Struk

p.Halaman Data Pemeriksaan

Halaman ini berisi data pemeriksaan dimana admin bisa melakukan penginputan hasil pemeriksaan.

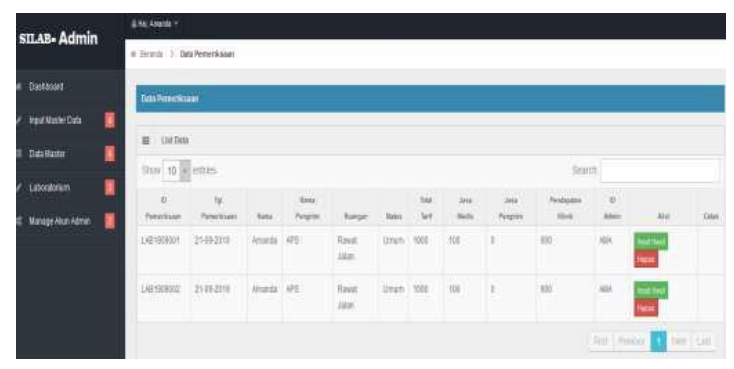

Sumber: Hasil Penelitian (2019)

Gambar 20. Data Pemeriksaan

q. Halaman Grafik pendapatan

Halaman ini berisi laporan pendapatan laboratorium dimana admin bisa melihat dan mencetak laporan tersebut berdasarkan harian,bulanan atau tahunan.

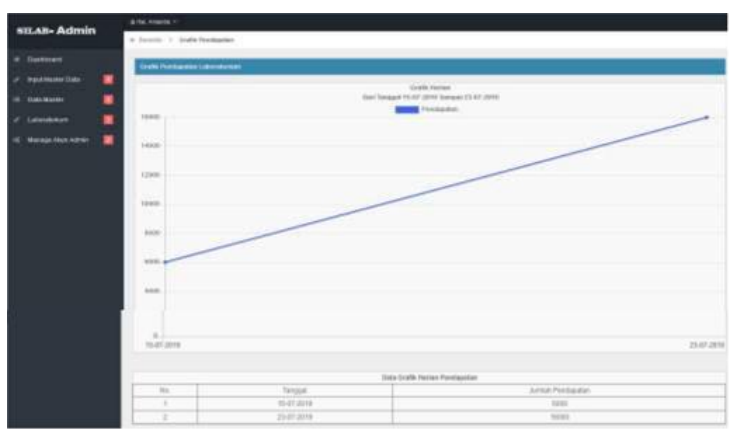

Sumber: Hasil Penelitian (2019)

Gambar 20. Data Pemeriksaan

r.Halaman Laporan Pendapatan

Halaman ini berisi laporan pendapatan klinik berdasarkan umum, jpk,jpkm dan bpjs.

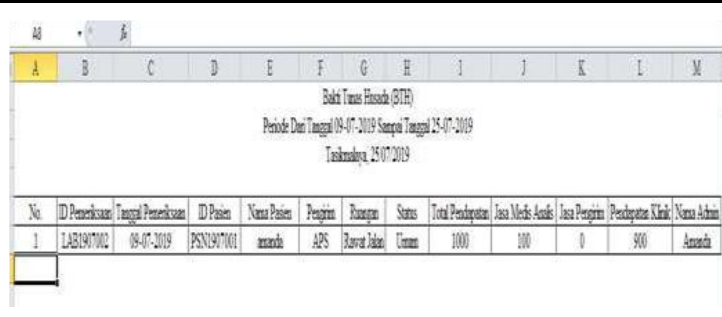

Sumber: Hasil Penelitian (2019)

Gambar 21. Halaman laporan pendapatan

s. Halaman Kartu Pasien

Setelah pemeriksa menginputkan data pasien maka otomatis kartu keluar secara otomatis.

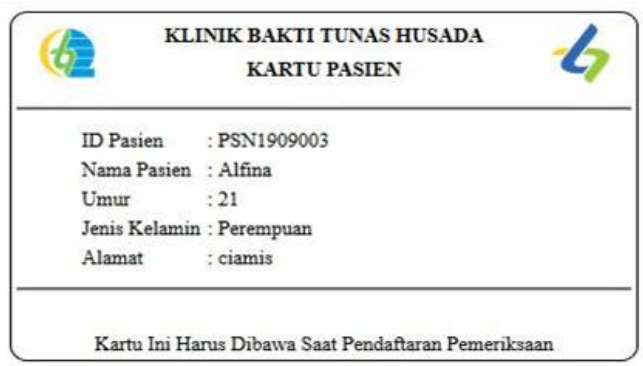

Sumber: Hasil Penelitian (2019)

Gambar 22. Halaman kartu pasien

\section{KESIMPULAN}

Dari hasil penelitian yang telah dilakukan, maka dapat diambil kesimpulan berdasarkan pertanyaan atas penelitian yang dikemukakan diatas bahwa dengan diterapkannya teknologi berbasis web, maka sistem informasi rekam medis hasil laboratorium ini bisa menjadi alternatif pemecahan masalah, ini dibuktikan dengan proses input data hasil pemeriksaan laboratorium pasien dapat dengan mudah dilakukan karena pemeriksa cukup memasukan hasilnya saja, pencetakan hasil pemeriksaan lebih cepat, pencetakan struk harga pemeriksaan keluar dengan otomatis bersamaan dengan hasil pemeriksaan, proses perhitungan dan pembagian pendapatan antara pemeriksa laboratoriuum, klinik dan dokter dihitung secara otomatis, pemeriksa mudah melihat laporan pendapatan setiap hari, setiap bulan dan setiap tahun dengan mudah dengan memasukan tanggal yang dibutuhkan. memudahkan dalam membuat kartu pasien, selain itu dengan adanya outpot laporan pendapatan berbentuk grafik bisa memberikan gambaran visual yang informatif. 


\section{REFERENSI}

A.S, R., \& Shalahuddin, M. (2014). Rekayasa Perangkat Lunak Terstruktur dan Berorientasi Objek. Bandung: Informatika.

Anori, S. R., Rukun, K., \& Huda, Y. (2016). Rancang Bangun Sistem Informasi Laboratorium SMKN 2 Payakumbuh Berbasis Web. Jurnal Vokasional Teknik Elektronika \& Informatika (Voteknika), 4(2), 85-95.
Suprianto, A., \& Matsea, A. A. F. (2018). Rancang Bangun Aplikasi Pendaftaran Pasien Online Dan Pemeriksaan Dokter Di Klinik Pengobatan Berbasis Web. Jurnal Rekayasa Informasi, 7(1), 48-58.

Tamara, D., \& Tulloh, R. (2018). Perancangan Dan Implementasi Sistem Informasi Laboratorium D3 Teknik Telekomunikasi Berbasis Web. In e-Proceeding of Applied Science (Vol. 4, pp. 2653-2662). 